\title{
Investigation of multiple intelligence of primary school students
}

\author{
Lukman Nulhakim *, Liska Berlian \\ Department of Science Education, Faculty of Teacher Training and Education, Universitas Sultan Ageng \\ Tirtayasa. Jalan Ciwaru Raya No. 25, Cipare, Serang, Banten, Indonesia \\ * Coressponding Author E-mail: lukman.nulhakim@untirta.ac.id
}

Received: 8 January 2020; Revised: 9 January 2020; Accepted: 10 July 2020

\begin{abstract}
The aim of this research is to investigate the ability of multiple intelligence (MI) of male and female students from primary school. The total sample was 71 students consisting of 35 experimental group students and 36 in the control group in a primary school in Cilegon City, 2016-2017 academic year. In this study, the experimental group consisted of male students using learning with the MI and the control group consisted of female students using learning with the MI approach. Analysis of data obtained from this study, using the Independent Sample t-test and Pearson Product Moment Correlation Coefficient. The findings of this study indicate that there is a statistically significant difference between the ability of $\mathrm{MI}$ in the experimental group and the control group, where the average score experimental group is higher. These results can be seen in the average score of MI ability in the experimental group is higher in visual-spatial, music, logicalmathematical, interpersonal and bodily-kinesthetic intelligence. The average score of MI ability in the control group is higher in verbal-linguistic, naturalistic, and intrapersonal. These concluded that the results of the Investigation of Multiple Intelligence (MI) of Primary School Students in the experimental group (male students) were better than the control group (female students).
\end{abstract}

Keywords: multiple intelligence, primary school students

How to Cite: Nulhakim, L., \& Berlian, L. (2020). Investigation of multiple intelligence of primary school students. Jurnal Inovasi Pendidikan IPA, 6(1), 101-113. doi:https://doi.org/10.21831/jipi.v6i1.29478

\section{INTRODUCTION}

In $21^{\text {st }}$ century learning, students must have the ability to solve problems, think critically, find and evaluate information and can productively collaborate and communicate with other students (Bråten \& Braasch, 2017). One of the challenges in the world of education lies in how to make students accustomed to critical and creative thinking in solving problems, so that educators are required to play an active role in the learning process (Voogt \& Knezek, 2008).

Student failure in schools is generally built as a lack of (academic) success in examinations, often a result of lack of participation, and is generally understood in a framework for understanding the disadvantages of education that identify social class, gender, ethnicity, and disability as agents of exclusion. and oppression. The mediating effect of "intelligence" on how classrooms and schools are organized, how systems prioritize certain students and certain abilities, and how certification is conducted and discriminates against many people can help us in understanding and combating educational disempowerment (Hanafin, 2014). It is observed that students possess almost all of these types of learning styles, but most of them are found as tactile and hearing learners. Three groups of intelligence: The types of naturalistic, visual, and kinesthetic intelligence receive the highest score. Analysis also shows that there are significant differences between men and women. It appears that most types of intelligence and learning styles have a moderate positive correlation (Şener \& Çokçalışkan, 2018). The research result showed the correlation between logical-mathematical, kinesthetic, naturalistic intelligence and visualspatial with referred properly in science teaching. In addition there is a correlation between kinesthetic and visual-spatial intelligence with science process skills, implying that multiple intelligence is related to science learning, where is that multiple intelligences relate to the teaching of science-preferred experiments. Among the nine different types of intelligence, only kinesthetic, logical, visual-spatial and naturalistic intelligence have a connection with science teaching that is preferred-experimentally oriented (Samsudin et al., 2015). 
Since it was found that students' mastery of concepts has increased after learning to use multiple intelligence-based learning and students are found to have moderate to very high interest in learning, it can be concluded that multiple intelligence-based learning has a significant influence on the mastery of the concepts of both students. and interest in learning material. Implementation of multiple intelligencebased learning is carried out systematically according to plan with reference to lesson plans that have been approved by experts. Students' mastery of concepts increases after being taught using multiple intelligence-based learning, referring to the results of their pretest and posttest scores in the concept material. Multiple intelligence-based learning attracts students' interest in learning material as evidenced by the Likert interest scale results which show that most students have a high interest in learning after being taught by using multiple intelligence-based learning (Pratiwi et al., 2018). The combination of various intelligences in lesson plans and MIA steps in classroom activities creates a meaningful learning experience (Astutie, 2017). This process results in increased student understanding and problem solving. It is important to note that with a methodology in which integrated MI strategies students feel more motivated (García et al., 2017).

Anitha et al. (2013) revealed that there were significant differences between the levels of dual intelligence of public school students and private school students. Girls have more multiple intelligences than boys. Public school students excel in three fields namely, logical, interpersonal and intrapersonal than private school students. Male students are good at spiritual/naturalistic intelligence. In general, female students have better conceptual knowledge than male students. The two-level multi-level instrument can be used as an alternative instrument to identify misunderstandings among students. (Cahyanto et al., 2019). As for MI-based teaching, teaching activities must be designed to develop different students' intelligence, increase their strengths, and improve their weaknesses. For this purpose, teachers must put aside their dominant intelligence, their interests, and preferences and integrate various activities in their classrooms. They better remember this that their bias towards specific intelligence may be boring and less fruitful. This study highlights the importance of paying further attention to individual differences, providing a more appropriate curriculum, and more material inspired by MI (Dolati \& Tahriri, 2017).

The activities to measure and explore more multiple intelligences are rarely conducted in schools, especially investigate talents, skills, interests, that are not yet to be the main focus of students in the process of learning (Akkuzu \& Akçay, 2011). Each student has a different intelligence, intelligence can be understood by observing their behaviour, such as their ability to understand an object, collect data, memorize and the learning process (Coban \& Dubaz, 2011). Good learning is an activity that can be done psychologically and physiologically. Psychological activities can be in the form of thinking, understanding, concluding listening, and analysing (Peden et al., 2018). Through the learning process can make each student become a human who has potential or intelligence.

The problem of intelligence and how intelligence must be defined has become an interesting field for many researchers. While some researchers rely on the Intelligence Quotient (IQ) test, which measures human intelligence by using intellectual functions or performance as a basis, and defines intelligence as the quantity measured by this test, others identify intelligence as the learning power someone has (Saban, 2015).

Consequently, intelligence researchers conduct their research with what appears to be different ideological tendencies. These trends seem to predict the types of findings that emerge from their research (Sternberg, 2014). Gardner states that he defines intelligence more broadly by rejecting traditional concepts, which argue that human intelligence can be measured objectively (Armstrong, 2009). Gardner claims that intelligence includes many abilities, which cannot be explained by only one factor, and that humans do not have unique intelligence (Sutcu et al., 2015) instead, all of these abilities and capacities exist in every human being to a minimum. Gardner defines intelligence as the ability to find and solve problems and make products that are valuable in one's cultural environment (Campbell et al., 2003; Gouws, 2007). Lists the intelligence characteristics as follows (Gardner, 1993): (1) Each of individual has the ability to improve and increase their intelligence; (2) Intelligence is not only can be changed, but can be taught to others too; (3) Intelligence is a multidimensional phenomenon resulting from interaction of the intellect and the brain; (4) Intelligence is a whole, complete in itself despite being multidirectional; (5) Each individual can become dominant in areas of the intelligence; (6) Various areas operate with each other, generally in harmony; (7) Many ways for every individual can be intelligent in each of area. 
Multiple intelligence is a new model of learning that helps students learn effectively (Al-Kalbani $\&$ Al-Wahaibi, 2015). If teachers can determine the intelligences (enhanced abilities) in each student and then teach to those enhanced abilities, students will learn better (Adcock, 2014). According to this study, students are not all will have the same dominant area of inteligence in the classroom situation. At the same time, the dominant intelligence of students areas have an effect on student's learning styles as well. For example, students who have strong verbal-linguistic intelligence learn better by hearing, talking, reading, discussing and communicating and interacting with others. Students who are strong in logical intelligence learn better by establishing the logical relationships between events, digitizing and calculating the properties of objects in a quantitative manner, and thinking over abstract relationships between events (Saban, 2015). Students can develop their potential and concern for the environment, learn about natural phenomena, and be able to understand and solve problems they encounter in the surrounding world (Kose \& Arslan, 2017). Hence, expresses that the best way to benefit from the theory is to behold the varied abilities and talents of students and arrange teaching practices according to these differences (Gardner, 2000). Here, the important point is organization of the educational environment by means appealing to all intelligence areas, not according to one specific intelligence area. The first step for teachers who want to apply the multiple intelligence theory to their classes efficiently must be to discover their own intelligence areas and become conscious of the theory.

Discovering multiple intelligence areas of helps give an idea of the intelligence areas used widely in their own lives, as well as to realize the areas of intelligence that require development (Wolff et al., 2018). Teachers perform a variety of activities in the process of learning teaching, but they often unintentionally exhibit preferences for activities that match their own strongest areas of intelligence (Lösch et al., 2017). Teachers may prefer some activities, which are not match with their intelligence areas, or they may add new and different activities, which are compatible with their own intelligence (Niemiec et al., 2006). Intelligence is a person's ability to respect themselves and others, understand people's feelings, the ability to follow a rule that applies, and the ability to communicate with people around (Flunger et al., 2017). Research results determining such a relationship between students' multiple intelligence areas and their students' academic success have not been observed in the literature search. This research is expected to contribute to this literature aspect. The aim of this research is to investigate the ability of multiple intelligence (MI) of male and female students from primary schools in Cilegon City, Banten Province, Indonesia.

Intelligence is flexible and vulnerable to improvement or deterioration. Humans are born with a set of genetically predisposed intelligence, which can be developed later on, depending on family, social, cultural and educational practices and experiences (Stanciu et al., 2011). Intelligence is a term that is difficult to define and gives rise to different understandings among scientists. Popular understanding of intelligence is often defined as a general mental ability to learn and apply knowledge in manipulating the environment, as well as the ability to think abstractly. Some other scientists argue that intelligence is a mental adaptation to new circumstances (Shearer \& Karanian, 2017). Measurement of intelligence on analytical abilities is measured by providing clear information needed in solving problems and only one correct answer is obtained from the correct problem-solving method. This answer is obtained from the experience and knowledge possessed by individuals. Classical psychometric view, intelligence is defined operationally as the ability to answer items on an intelligence test (Yerizon et al., 2018). The result of test score for an ability is supported by statistical techniques. These techniques compare the responses of subjects at different ages, the real correlation of these test scores at age and different test tests confirm the understanding that general intelligence, which is shortly called eg, does not change much as you age, exercise, or experience, it is an innate nature or individual talent (Butler et al., 2017).

Multiple intelligences are various talents and skills of students to solve problems in learning. Multiple intelligence theories emphasize the variety of ways people show their talents in intelligence and between intelligence. Multiple intelligence was first introduced by Gardner in his book entitled Frame of Mind (Hajhashemi, Caltabiano, \& Anderson, 2018). Thus, the theory of multiple intelligences postulated by Howard Gardner (1983) is an intelligence model that classifies human intelligence into specific modalities; Different intelligence is understood as a personal tool and a person may be more talented in some intelligences than others (Mirzazadeh, 2012). The Theory of Multiple Intelligences. The theory was developed based on Gardner's belief that intelligence is not only determined by one factor, but from a number of factors. In 1985, Gardner explained in his book seven types of intelligence, namely: (1) spatial-space (Visio-spatial, (2) linguistic (linguistics), (3) interpersonal, (4) music (music), 
(5) physical-kinesthetic (bodily-kinesthetic), (6) interpersonal and (7) logical-mathematical (logicalmathematical). Seven types of intelligence in subsequent development, because the development of social and cultural in society are divided into eight intelligences and then divided to nine intelligences, namely (8) naturalist, and (9) existential or spiritual (Jung \& Chang, 2017).

Butler et al. (2017) describe too that the theory of multiple intelligences developed by Howard Gardner, that human intelligence is not only limited to one type of intelligence, but also to various intelligences possessed by humans. Gardner's multiple intelligence theory is divided into seven intelligences: (1) Linguistic intelligence is intelligence in using language which includes the ability to express opinions and thoughts in verbal and written form. (2) Music intelligence is intelligence in understanding sounds, rhythms derived from musical instruments and the ability to understand tones in humming or singing. (3) Mathematical logical intelligence is intelligence related to understanding patterns, numbers and symbols. (4) Spatial intelligence is human intelligence which related to understand images, space and multiple forms. (5) Kinesthetic intelligence is human intelligence which refered to activity of physical related to move, to touch, and to balance the body. (6) Personal intelligence is human intelligence for example that they deals with human social interaction which are in understanding themselves and others.

The application of MI Gardner's theory helps promote an inclusive environment by assessing that all individuals have strengths in different fields. The eight intelligences identified by Gardner can be used individually or in conjunction with one another to enable students to identify the learning styles they like, and to allow students access to explore other preferred learning styles. Utilizing strategies that accommodate MI students in class allows teachers to create an inclusive classroom environment, by differentiating content related to eight intelligences. It promotes teaching in a variety of ways to meet individual differences and ensure education is accessible for all (Murray \& Moore, 2012).

\section{METHOD}

In this study, the experimental group consisted of male students using learning with the multiple intelligence (MI) and the experimental control group consisted of female students using learning with the MI approach. The total study sample was 71 students consisting of 35 experimental group students and 36 in control group in primary schools in Cilegon City, 2016-2017 academic year. In this study, the experimental group consisted of male students using learning with the MI and the experimental control group consisted of female students using learning with the MI approach (Figure 1). Analysis of data obtained from this study, using Descriptive Statistics, Independent Sample t-test and Pearson Product Moment Correlation Coefficient. Because it is impossible to reach the whole of this teaching world, a sample selection has been concluded. A simple random sampling method is used in sample selection. This is a selection process that is not biased because it takes into account the possibility of being equal and independent in selecting samples for each unit in the universe (Akkuzu \& Akçay, 2011).

Processing data using the SPSS program was used to analyze the data in this study, and a significance level of 0.05 was used for all analysis. In addition, the normal distribution of data was tested to determine the type of analysis suitable for the data collected in this study. For this purpose, the Kolmogorov-Smirnov (K-S) test is used. The results are detailed in Table 1.

Table 1. Test of Normality

\begin{tabular}{lccc}
\hline & \multirow{2}{*}{ Students' MI } & \multicolumn{2}{c}{ Kolmogorov-Smirnov } \\
\cline { 2 - 4 } & Statistic & df & Sig. \\
\hline Verbal-Linguistic & .077 & 71 & .180 \\
Visual-Spatial & .082 & 71 & .200 \\
Naturalistic & .088 & 71 & .051 \\
Musical & .086 & 71 & .061 \\
Logical-Mathematical & .101 & 71 & .055 \\
Intrapersonal & .076 & 71 & .065 \\
Interpersonal & .086 & 71 & .200 \\
Bodily-Kinesthetic & .071 & 71 & .100 \\
\hline
\end{tabular}

Based on Table 1, it was determined that the data obtained from the Kolmogorov-Smirnov (K-S) test represented a normal distribution ( $\mathrm{p}>.05)$. 
Jurnal Inovasi Pendidikan IPA, 6 (1), 2020 - 105

Lukman Nulhakim, Liska Berlian

\begin{tabular}{|c|c|c|}
\hline Group & Treatment \\
\hline Experiment & $\longrightarrow$ & Information \\
\hline Control & $\longrightarrow$ & Male \\
\hline & Learning with MI Approach & Female \\
\hline
\end{tabular}

Figure 1. Method of Research

\section{RESULTS AND DISCUSSION}

Every child has strong and weak sides no matter what area of intelligence. With the condition that only one or two areas of intelligence are used, students whose types of intelligence do not occur among those used at school cannot improve their bright side, completing learning in a long period without enjoying or never managing to learn (Yalmanci \& Gozum, 2013). The findings of this study indicate that there is a statistically significant difference between the ability of MI in the experimental group and the control group. Based on the results of the Independent Sample t-test were used the following data of Figure 1 .

Table 2. Results of Independent Sample t-test

\begin{tabular}{lcccc}
\hline Group & & N & Average & SD \\
\hline Experiment & Post-test & 35 & 72.40 & 11,60 \\
& Pre-test & 35 & 68.20 & 10.40 \\
Control & Post-test & 36 & 70.70 & 10.90 \\
& Pre-test & 36 & 67.20 & 10,20 \\
\hline
\end{tabular}

Based on Table 2, information is obtained that the average value of the post-test experimental group is 72.40 with a standard deviation of 11.60 . While the average value of the control group posttest is 70.70 with a standard deviation of 10.90 . The post-test mean results from the two groups showed that the experimental class was on average higher than the control class with a difference of 8.62. From the results above it is found that the $\mathrm{T}$-Value with $\mathrm{DF}=71$ shows a value of 3.04. Based on the T-Test table, T-Value 3.04 has a significance level of 0.005 . While the results of the calculation obtained a probability value (P-Value) which is 0.003 where the value is smaller than the significance level of 0.005 . So, it can be concluded that the value of the statistically significant difference between the ability of MI in the experimental group and the control group, where the average experimental group is higher. This results is in accordance with Yalmanci and Gozum (2013), where is after application; in the final test and the permanent test, the multiple intelligence method applied to the experimental group had a significant difference compared to the traditional educational method applied to the control group.

Based on data for the implementation of learning already using multiple intelligence approach. There are nine multiple intelligences that have been observed as follows: (1) Linguistics: (a) listening to the teacher's explanation 100\%; (b) speaking and expressing opinions 50\%; (c) reading books and literature 71.4\%. (2) Mathematical logic: (a) asking questions 50\%; (b) numeracy and using 78.6\%; (c) completing and doing 50\% questions. (3) Visual spatial: (a) sort the image according to the instructions 71.4\%; (b) draw 28.6\%; (c) make a chart 35.7\%. (4) Kinesthetic: (a) imitating the teacher's movement 42.9\%; (b) making crafts $14.3 \%$; (c) moving, moving places or mobility $71.4 \%$. (5) Musicals: (a) singing or humming $57.1 \%$; (b) listening to music $57.1 \%$; (c) clapping 71.4\%. (6) Interpersonal: (a) doing $100 \%$ group work; (b) guiding friends in completing $92.9 \%$ tasks; (c) doing $100 \%$ cooperation. (7) Intrapersonal: (a) work independently $85.7 \%$; (b) prepare and manage their own completeness $71.4 \%$, (c) show seriousness in the task $64.3 \%$. (8) Naturalistic: (a) observing the environment around flora or fauna $85.7 \%$; (b) observing natural phenomena (earthquakes, floods, landslides) 85.7\%; (c) observing celestial bodies $85.7 \%$. (9) Spiritual: perform worship (ablution and prayer) 100\%; (b) say the sentence toyib (thank God, Subhanallah) 100\%; (c) do 100\% prayer activities.

Based on Table 3, information is obtained that can be seen in the average score ability MI of the experimental group higher in visual-spatial, music, logical-mathematical, interpersonal and bodilykinesthetic intelligence. The average score of ability MI control group is higher in verbal-linguistic, naturalistic, intrapersonal. These concluded that the results of the Investigation of Multiple Intelligence (MI) of Primary School Students in the control group (male students) were better than the control group (female students). Mustafa et al. (2014) showed that linguistic intelligence was ranked first, while spatial intelligence came last, and that there were no statistically significant differences in intrapersonal intelligence, while there were statistically significant differences in the residual intelligence associated with gender variables. 
Jurnal Inovasi Pendidikan IPA, 6 (1), 2020 - 106

Lukman Nulhakim, Liska Berlian

Table 3. Test of Normality

\begin{tabular}{|c|c|c|c|}
\hline \multirow{2}{*}{ Students' MI } & \multicolumn{2}{|c|}{ Average Post-test } & \multirow{2}{*}{ Information } \\
\hline & Experiment $(\mathrm{P})$ & Control (C) & \\
\hline Verbal-Linguistic & 70.40 & 75.60 & $E<C$ \\
\hline Visual-Spatial & 70.20 & 68.80 & $E>C$ \\
\hline Naturalistic & 69.20 & 74.20 & $E<C$ \\
\hline Musical & 73.40 & 70.40 & $E>C$ \\
\hline Logical-Mathematical & 75.60 & 73.40 & $E>C$ \\
\hline Intrapersonal & 68.80 & 73.40 & $\mathrm{E}<\mathrm{C}$ \\
\hline Interpersonal & 74.20 & 69.20 & $E>C$ \\
\hline Bodily-Kinesthetic & 71.80 & 70.10 & $E>C$ \\
\hline
\end{tabular}

These result are in accordance with Shearer (2018) that describes independent leadership for lifelong learning is the ultimate goal for one's education-fostering knowledge that a person has intellectual abilities that value and it can be developed and used to meaningfully contribute to community. The perspective of multiple intelligences contributes to this effort. Understanding how education can develop intrapersonal intelligence brings us back to the important integration of self in context and culture.

The multiple intelligence, intrapersonal aspects of work are in accordance with the research Hajhashemi, Caltabiano, \& Anderson (2018) shows the quantitative findings that are higher in Intrapersonal intelligence and Existential intelligence. In addition, it is supported by research Yerizon et al. (2018) that suitable knowledge for students with Intrapersonal and good response to the resulting work sheet for understanding the concept learned. The students with intrapersonal intelligence prefer to study on their own, while students with interpersonal intelligence prefer to study together. The theory of multiple intelligences expresses the pluralistic view of the human mind (Yerizon et al., 2018). Spiritual intelligence (SI) is gaining great interest of scholars and practitioner's (Munawar \& Tariq, 2018). The growing importance of SI has changed the meaning of success in organizations SI emerged beyond the rational and emotional abilities like intelligence quotient (IQ) and emotional quotient. Integrated the 21 psychological concepts of spiritualism and intelligence into a new concept identified as "Spiritual intelligence".

The $21^{\text {st }}$ skills that comprise spiritual intelligence and in doing, so teaches students is the steps to begin developing the teachers's spiritual intelligence (Shearer \& Karanian, 2017). One of many ways to implement active learning in the learning process is to apply teaching materials and learning models that are able to get students directly involved in forming the concepts being learned (Utami \& Aznam, 2020). (Uswatun \& Rohaeti, 2015) said that the science learning tools is one of the learning variables that is directly related to the quality of learning. The availability of quality science learning tools is expected to improve the quality of learning. For the statistics board teacher room and educator competencies which need to be improved again (Irby \& O'Sullivan, 2018). For the implementation of learning the teacher has implemented learning that encourages multiple intelligence learning that can develop the potential of students in each learning (Jung \& Chang, 2017). In Bråten and Braasch (2017), the implementation of teacher learning used the learning based on multiple intelligence. The assessment stage is the assessment of learning through daily, midterm, and end of semester tests. Phase outcomes, this stage includes: results. This stage is an assessment of learning outcomes in accordance with educational process standards which include cognitive, affective and psychomotor assessment (Based on the results of the Independent Sample t-test were used the following data in Table 3.

Table 4. Independent Sample t-test Results of Average Scores of Students' Multiple Intelligence

\begin{tabular}{lcccccccc}
\hline \multirow{2}{*}{ Students' Multiple intelligence } & \multicolumn{9}{c}{ Levene's test } \\
\cline { 2 - 8 } & $\mathrm{N}$ & Average Score & $\mathrm{Ss}$ & $\mathrm{f}$ & $\mathrm{p}$ & $\mathrm{sd}$ & $\mathrm{t}$ & $\mathrm{P}$ \\
\hline Verbal-Linguistic & 71 & 34.26 & .200 & 1.614 & .070 & 77 & 1.880 & .054 \\
Visual-Spatial & 71 & 33.69 & .200 & 3.710 & .054 & 77 & 1.212 & .044 \\
Naturalistic & 71 & 36.00 & .051 & 1.614 & .463 & 77 & 1.090 & .034 \\
Musical & 71 & 34.23 & .061 & 3.710 & 612 & 77 & 1.362 & .064 \\
Logical-Mathematical & 71 & 36.36 & .055 & 2.514 & .463 & 77 & 1.780 & .034 \\
Intrapersonal & 71 & 30.38 & .200 & 4.810 & .863 & 77 & 1.910 & .074 \\
Interpersonal & 71 & 37.71 & .200 & 1.574 & .963 & 77 & 1.010 & .044 \\
Bodily-Kinesthetic & 71 & 32.10 & .200 & 1.804 & .194 & 77 & 1.342 & .064 \\
\hline
\end{tabular}

$n=71, p<.05$ 
Based on Table 4, the independent sample t-test results of the average scores of students' multiple intelligence areas in terms of class-level variable are given. According to the findings in Table 5, there was no statistically significant difference on Verbal-Linguistic $=1.880, \mathrm{p}>.05$, visual-spatial linguistic [ $\mathrm{t}$ $(77)=1.212, \mathrm{p}>.05$, nature $[\mathrm{t}(77)=1.090, \mathrm{p}>.05$, musical $[\mathrm{t}(77)=1.363, \mathrm{p}>.05]$, logical-mathematical [t (77) $=1.780, p>.05]$, intrapersonal $[t=1.910, p>.05]$, interpersonal $[t(77)=1.010, p>.05]$ and bodilykinesthetic [ $\mathrm{t}=1.341, \mathrm{p}>.05]$ intelligence area average scores in terms of the grade level variable. In another words, it can be said the grade level variable does not have an impact on the average score of the students' multiple intelligence.

The Students' Multiple Intelligences used in the study aims to help an individual establish a relationship between experiences students' in different intelligence areas. This evaluation, gives insight into the fields of intelligence, which people use in their works and lives, so it will make easier for them to pay attention to the areas of intelligence they need to improve (Yerizon et al., 2018). According to a study made (Adcock, 2014). Teachers indicated at a rate of approximately seventy-five percent that the multiple intelligence theory helped them meet the individual needs of their students. Teachers believed that teory of multiple intelligence was imperative in showing the diversity of their student needs and give them a variety of instructional methods to use. From this viewpoint, it was detected that students had the highest scores in the logical-mathematical area and the lowest score in the musical area when the class average multiple intelligence scores were reviewed. This result is in accordance with Winarti et al. (2019). Her research yields important findings from the feasibility of MI-based learning strategies applied in science lessons. Based on the results, it can be concluded that there is a significant influence of MI strategy on the development of MI and SPS students. The implementation of MI-strategies in this study increases MI and SPS students. The six stages of the MI-based learning process, which consists of (1) self-reflection; (2) introduction of concepts; (3) formulation of questions; (4) exploration of concepts; (5) talent show; and (6) conclusion formulation, proved to be effective in increasing five types of intelligence, namely interpersonal, intrapersonal, visual-spatial, kinesthetic and musical intelligence. Simple learning strategy steps make this strategy easy to use in the classroom, without having to make special programs as applied to previous research. The results of this study contribute to improving the quality of science learning in the future. Learning is no longer oriented towards increasing academic ability, but also trying to improve science process skills and student potential.

Exploring learning styles and the different types of intelligence of students can enable students to identify their strengths and weaknesses and learn from them. It is also important for teachers to understand the student's learning styles and their multiple intelligences, because teachers can identify with careful their design aims and many activities so that teachers can teach with student's different intelligences and student-centered activities design (Şener \& Çokçalışkan, 2018). Gunduz and Ozcan (2016) showed that preschool students achieved high levels of development in linguistic/verbal intelligence, spatial intelligence, bodily kinesthetic and naturalist intelligence fields through the use of storytelling methods. In addition, some positive effects are also seen in logical-mathematical intelligence, musical intelligence, interpersonal intelligence, and intrapersonal intelligence. Napiere (2012) describes too that students had dominant musical-rhythm and spatial-visual intelligence; and they prefer learning through linguistic and intrapersonal tools. (Napiere, 2012) used dominant modes which are intrapersonal and logic-based modes; and assessment tools used related to interpersonal and logical-mathematical intelligence. The results of the correlation show that students who have strong intrapersonal intelligence tend to prefer learning in a linguistic way. Each delivery mode used in class is significantly related to each assessment tool.

Many researchs revealed the same findings with this result study. Kaur and Chhikara (2008) describe that the majority of respondents were found to have an average level of intelligence for all nine components of multiple intelligences. The Mean scores of boys and girls for linguistic intelligence $(\mathrm{z}=$ 2.44), scores for logical (5.22), scores for musical (4.45) and scores forbodily kinesthetic (3.03). This describe that there were the significant differences between them. It was found that in the case of linguistic and musical intelligence girls took a bit of leadership while boys were ahead of girls in logical and bodily kinesthetic intelligence. İkiz and Çakar (2010) describe that there were statistically significant differences in the means of the multiple intelligence subscales of participants according to their level of academic achievement. According to Tukey's analysis, participants who had the lowest level of academic achievement (Accumulative Grade 1) had lower verbal linguistic abilities than students who had middle and upper levels of academic achievement; who have low levels of academic achievement 
have lower verbal linguistic abilities than students whose level of academic achievement is above and intermediate. Participants who have low levels of academic achievement have lower logical-mathematical abilities than students who have high levels of academic achievement. Participants, who have the lowest level of academic achievement, have lower interpersonal and intrapersonal skills than others. This result is in accordance with Gohar and Sadeghi (2015) that describe EFL students who are more capable have higher verbal intelligence, suggesting that students who are more successful may be smarter 'verbally' than their less capable peers. Finally, verbal and visual intelligence - with the highest average scores - are the two types of intelligence most widely used by high and low achievers. As (Yalmanci \& Gozum, 2013) say, MI Gardner's theory has two important advantages in education. First, it paves the way for planning educational programs in such a way that students realize their potential and move towards their desires. Second, it is possible for us to reach students who are more active because learning will be more interesting in conditions where students are trained through the use of this intelligence.

Hajhashemi, Caltabiano, Anderson, et al. (2018) describes in his research that overall multiple intelligence is significantly positively correlated with learning experiences but not with student motivation. Although these findings reveal a significant difference between respondents' MI profiles and their age categories, it was revealed that all students had lower Existential intelligence. Further analysis between gender and the MI subscale also showed significant differences between gender and LogicalMathematical and Intrapersonal intelligence. However, a negligible significant relationship was found between the two subscales of the Learning Experience Inventory and the age of the participants.

Cognitive research shows that boys and girls appear different on certain types of math tests, even though there are biological differences in gender. In general, boys are born with an interest in finding out how the system works, while girls are naturally more focused on understanding the mental states of others. Conversely, some researchers say little about innate gender differences that children spend years in a sea of cultural and academic stimuli that can affect their performance (Mnastersky, 2005). According to the results of this study, it was found that gender proved effective in multiple intelligences. That is, girls have a higher score than boys on verbal linguistic abilities and musical abilities. Actually gender differences in multiple intelligences have been investigated and important research areas in the literature. Much of the literature reports that there are significant sex differences in self-estimation of multiple intelligences, which are parallel with the results of this study, and intelligence of factors (Barnard \& Olivarez, 2007; Furnham, 2000; Furnham et al., 2001; Furnham \& Akande, 2004; Furnham \& Chamorro-Premuzic, 2005; Furnham \& Mottabu, 2004); However some indicate that there are no significant gender differences at the subscale level or from examining the total score of multiple intelligences. In addition, there were no significant gender differences in intelligence estimates that schools valued as a combined total score of mathematical intelligence and logical linguistics (Barnard \& Olivarez, 2007).

Neto et al. (2008) investigated the relationship between sex, attitudes toward intelligence and selfintelligence multiple intelligence for self and parents among adolescents in secondary schools. As shown in this study, men rated themselves higher on overall IQ, mathematics, spatial, intrapersonal, spiritual and naturalistic compared to women. Multiple regression indicates that verbal, logical and intrapersonal intelligence is a significant predictor of self and parents as a whole IQ estimate. (Delgoshaei \& Delavari, 2012) describe too that applying the MI approach in the classroom as an educational method resulted in improvements in all five domains of pre-school children's cognitive development with $99 \%$ significance. This result is in accordance with Ratnasari et al. (2018) that learning with a multiple intelligence approach through quantum teaching models are more effective for improving scientific and scientific attitudes learning outcomes rather than learning by quantum teaching model. The results showed that the worksheet based on Multiple Intelligences effectively optimized students' creative thinking Luthfiana et al. (2018) and Hutasuhut et al. (2019) revealed his research that compound intelligencebased explanatory text teaching materials are feasible, easy and effective to use in learning in grade 11 vocational high schools. The present paper looks at internet as a suitable teaching tool which can accommodate diverse intelligences and learning preferences of multiple learners and can extend a great language teaching/learning experience. It is a fact that no two students are the same as far as the attributes and learning styles are concerned (Sengupta, 2017).

By developing multiple intelligences in the classroom, it will give students the opportunity to learn authentically based on their needs, interests and talents. Anitha et al. (2013) said that multiple intelligence is needed to people for reasoning, learning quickly solving the problem, thinking abstractly, 
planning, comprehending the complex ideas, and learning from experience, because intelligence is not merely learning many books, it's just a narrow academic skill. But multiple intelligence reflects a deeper and broader competency for integrating our surroundings. Then by developing multiple intelligences in the classroom, it will make students enjoy the learning process and will feel comfortable and confident. Multiple intelligences also pay attention to individual differences in the learning process (Fitriani \& Syafe'i, 2014). Therefore, it is suggested that the Multiple Intelligence Theory can still function as a determining factor in the planning program for teaching reading despite theoretical, conceptual, and empirical criticism of the idea (Mobashshernia \& Aghazadeh, 2018).

\section{CONCLUSION}

This study shows that there are statistically significant differences between the ability of MI in male students and female students, where the score average of male students is higher. These results can be seen in the average score of MI ability of male students is in visual-spatial, musical, logicalmathematical, interpersonal and physical kinesthetic intelligence. The score average of MI ability of female students is higher in verbal-linguistic, naturalistic, intrapersonal. It was concluded that the results of the Multiple Intelligence Investigation of primary school students in male students were better than female students.

\section{REFERENCES}

Adcock, P. K. (2014). The longevity of multiple intelligence theory in education. Delta Kappa Gamma Bulletin, 80(4), 50.

Akkuzu, N., \& Akçay, H. (2011). The design of a learning environment based on the theory of multiple intelligence and the study its effectiveness on the achievements, attitudes and retention of students. Procedia Computer Science, 3, 1003-1008. https://doi.org/10.1016/j.procs.2010.12.165

Al-Kalbani, M. S., \& Al-Wahaibi, S. S. (2015). Testing the multiple intelligences theory in Oman. Procedia - Social and Behavioral Sciences, 190, 575-581. https://doi.org/10.1016/j.sbspro.2015.10.001

Anitha, T. S., Vannessa, J., \& Sreelakshmi, G. (2013). A study on the multiple intelligence levels of Secondary school students of Government and Private schools in Secunderabad. IOSR Journal of Research \& Method in Education (IOSR-JRME), 3(4), 12-18. https://www.iosrjournals.org/iosrjrme/papers/Vol-3 Issue-4/C0341218.pdf?id=7370

Armstrong, T. (2009). Multiple intelligences in the classroom. ASCD.

Astutie, D. D. (2017). Teaching English using a multiple intelligences approach. English Education Journal, 8(2), 245-257. http://www.jurnal.unsyiah.ac.id/EEJ/article/view/7232

Barnard, L., \& Olivarez, A. (2007). Self-estimates of multiple, G factor, and school-valued intelligences. North American Journal of Psychology, 9(3), 501-510. https://www.questia.com/library/journal/1G1-173513549/self-estimates-of-multiple-g-factorand-school-valued

Bråten, I., \& Braasch, J. L. G. (2017). Key issues in research on students' critical reading and learning in the 21st Century information society. In Improving Reading and Reading Engagement in the 21st Century (pp. 77-98). Springer Singapore. https://doi.org/10.1007/978-981-10-4331-4_4

Butler, H. A., Pentoney, C., \& Bong, M. P. (2017). Predicting real-world outcomes: Critical thinking ability is a better predictor of life decisions than intelligence. Thinking Skills and Creativity, 25, 38-46. https://doi.org/10.1016/j.tsc.2017.06.005

Cahyanto, M. A. S., Ashadi, A., \& Saputro, S. (2019). An analysis of gender difference on students' misconceptions in learning the material classification and its changes. Jurnal Inovasi Pendidikan IPA, 5(2). https://doi.org/10.21831/jipi.v5i2.26613

Campbell, L., Campbell, B., \& Dickinson, D. (2003). Teaching \& learning through multiple intelligences (3rd ed.). Allyn and Bacon.

Coban, S., \& Dubaz, İ. (2011). The relationship between active learning models in music lessons in elementary schools and multiple intelligence areas. Procedia - Social and Behavioral Sciences, 
28, 684-690. https://doi.org/10.1016/j.sbspro.2011.11.129

Delgoshaei, Y., \& Delavari, N. (2012). Applying multiple-intelligence approach to education and analyzing its impact on cognitive development of pre-school children. Procedia - Social and Behavioral Sciences, 32, 361-366. https://doi.org/10.1016/j.sbspro.2012.01.054

Dolati, Z., \& Tahriri, A. (2017). EFL teachers' multiple intelligences and their classroom practice. SAGE Open, 7(3), 215824401772258. https://doi.org/10.1177/2158244017722582

Fitriani, D., \& Syafe'i, A. F. R. (2014). Developing multiple intelligences in teaching English for young learners. Journal of English Language Teaching, 3(1), 189-194. http://ejournal.unp.ac.id/index.php/jelt/article/view/4375

Flunger, B., Trautwein, U., Nagengast, B., Lüdtke, O., Niggli, A., \& Schnyder, I. (2017). A personcentered approach to homework behavior: Students' characteristics predict their homework learning type. Contemporary Educational Psychology, 48, 1-15. https://doi.org/10.1016/j.cedpsych.2016.07.002

Furnham, A. (2000). Thinking about intelligence. The Psychologist, 13(10), 510-515. https://thepsychologist.bps.org.uk/volume-13/edition-10/thinking-about-intelligence-0

Furnham, A., \& Akande, A. (2004). African parents' estimates of their own and their children's multiple intelligences. Current Psychology, 22(4), 281-294. https://doi.org/10.1007/s12144-004-1034-X

Furnham, A., \& Chamorro-Premuzic, T. (2005). Estimating one's own and one's relatives' multiple intelligence: A study from Argentina. The Spanish Journal of Psychology, 8(1), 12-20. https://doi.org/10.1017/S1138741600004911

Furnham, A., Hosoe, T., \& Tang, T. L.-P. (2001). Male hubris and female humility? A crosscultural study of ratings of self, parental, and sibling multiple intelligence in America, Britain, and Japan. Intelligence, 30(1), 101-115. https://doi.org/10.1016/S0160-2896(01)00080-0

Furnham, A., \& Mottabu, R. (2004). Sex and culture differences in the estimates of general and multiple intelligence: A study comparing British and Egyptian students. Individual Differences Research, 2(2), 82-96.

García, C. M., Ramiro, S. S., \& Pérez, M. del M. S. (2017). The effectiveness of integrating multiple intelligences strategies in a bilingual education programme: A study of writing skills. International Journal of Education and Research, 5(2), 91-106. https://www.ijern.com/journal/2017/February-2017/08.pdf

Gardner, H. E. (1993). Multiple intelligences: The theory in practice. Basic Books.

Gardner, H. E. (2000). Intelligence reframed: Multiple intelligences for the 21st century. Hachette UK.

Gohar, M. J., \& Sadeghi, N. (2015). Gardner's Multiple Intelligence Theory and foreign language achievement. International Journal of English and Education, 4(1), 206-216.

Gouws, F. E. (2007). Teaching and learning through multiple intelligences in the outcomes-based education classroom. Africa Education Review, 4(2), 60-74. https://doi.org/10.1080/18146620701652705

Gunduz, N., \& Ozcan, D. (2016). The development of multiple intelligence with storytelling. International Journal of Educational Sciences, 15(1-2), 242-251. https://doi.org/10.1080/09751122.2016.11890533

Hajhashemi, K., Caltabiano, N., \& Anderson, N. (2018). Multiple intelligences, motivations and learning experience regarding video-assisted subjects in a Rural University. International Journal of Instruction, 11(1), 167-182. https://doi.org/10.12973/iji.2018.11112a

Hajhashemi, K., Caltabiano, N. J., Anderson, N., \& Tabibzadeh, S. A. (2018). Students' multiple intelligences in video-assisted learning environments. Journal of Computers in Education, 5(3), 329-348. https://doi.org/10.1007/s40692-018-0107-z

Hanafin, J. (2014). Multiple intelligences theory, action research, and teacher professional development: The Irish MI project. Australian Journal of Teacher Education, 39(4), 126-141. https://doi.org/10.14221/ajte.2014v39n4.8

Hutasuhut, I. A. R., Lubis, M., \& Daulay, S. (2019). Teaching material development of explanation text 
based on multiple intelligences on 11th Grade Students in Vocational High School 1 Padangsidimpuan. Budapest International Research and Critics in Linguistics and Education (BirLE) Journal, 2(4), 363-370. https://doi.org/10.33258/birle.v2i4.523

İkiz, F. E., \& Çakar, F. S. (2010). The relationship between multiple intelligences and academic achievements of second grade students. Mehmet Akif Ersoy Üniversitesi Sosyal Bilimler Enstitüsü Dergisi, 2(3), 83-92. https://doi.org/10.20875/SB.38716

Irby, D. M., \& O'Sullivan, P. S. (2018). Developing and rewarding teachers as educators and scholars: remarkable progress and daunting challenges. Medical Education, 52(1), 58-67. https://doi.org/10.1111/medu.13379

Jung, J.-H., \& Chang, D.-R. (2017). Types of creativity-Fostering multiple intelligences in design convergence talents. Thinking Skills and Creativity, 23, 101-111. https://doi.org/10.1016/j.tsc.2016.12.001

Kaur, G., \& Chhikara, S. (2008). Assessment of multiple intelligence among young adolescents (12-14 years). Journal of Human Ecology, 23(1), 7-11. https://doi.org/10.1080/09709274.2008.11906048

Kose, U., \& Arslan, A. (2017). Optimization of self-learning in Computer Engineering courses: An intelligent software system supported by Artificial Neural Network and Vortex Optimization Algorithm. Computer Applications in Engineering Education, 25(1), 142-156. https://doi.org/10.1002/cae.21787

Lösch, T., Lüdtke, O., Robitzsch, A., Kelava, A., Nagengast, B., \& Trautwein, U. (2017). A wellrounded view: Using an interpersonal approach to predict achievement by academic self-concept and peer ratings of competence. Contemporary Educational Psychology, 51, 198-208. https://doi.org/10.1016/j.cedpsych.2017.07.003

Luthfiana, A., Ambarita, A., \& Suwarjo, S. (2018). Developing worksheet based on multiple intelligences to optimize the creative thinking students. JIPM (Jurnal Ilmiah Pendidikan Matematika), 7(1), 1. https://doi.org/10.25273/jipm.v7i1.2430

Mirzazadeh, M. (2012). Impacts of multiple intelligences on learning English in the ESL classroom. American Journal of Scientific Research, 60, 64-74.

Mnastersky, R. (2005). Studies show biological differences in how boys and girls learn about math, but social factors play a big role too. Chronicle of Higher Education, 51(26), A1-A16.

Mobashshernia, R., \& Aghazadeh, S. M. (2018). The relationship between the interpersonal intelligence and reading comprehension achievement of Iranian bilingual and multilingual EFL learners. International Journal of Research in English Education, 3(2), 8-9.

Munawar, K., \& Tariq, O. (2018). Exploring relationship between spiritual intelligence, religiosity and life satisfaction among elderly Pakistani Muslims. Journal of Religion and Health, 57(3), 781795. https://doi.org/10.1007/s10943-017-0360-x

Murray, S., \& Moore, K. (2012). Inclusion through multiple intelligences. Journal of Student Engagement: Education Matters, 2(1), 42-48. https://ro.uow.edu.au/jseem/vol2/iss1/8/

Mustafa, S. A. Y., Abu Jado, S., \& Onoz, S. (2014). Types of multiple intelligences among undergraduate students at Yarmouk University in light of Gardner's theory. International Journal of Humanities and Social Science, 4(6), 140-153. http://www.ijhssnet.com/journals/Vol_4_No_6_April_2014/14.pdf

Napiere, M. B. (2012). Multiple intelligence-based learning preferences of students, modes of delivery and assessment tools used in Lourdes College. IAMURE International Journal of Education, 1(1). https://ejournals.ph/article.php?id=825

Neto, F., Ruiz, F., \& Furnham, A. (2008). Sex differences in self-estimation of multiple intelligences among Portuguese adolescents. High Ability Studies, 19(2), 189-204. https://doi.org/10.1080/13598130802504387

Niemiec, C. P., Lynch, M. F., Vansteenkiste, M., Bernstein, J., Deci, E. L., \& Ryan, R. M. (2006). The antecedents and consequences of autonomous self-regulation for college: A self-determination theory perspective on socialization. Journal of Adolescence, 29(5), 761-775. 
https://doi.org/10.1016/j.adolescence.2005.11.009

Peden, M. E., Okely, A. D., Eady, M. J., \& Jones, R. A. (2018). What is the impact of professional learning on physical activity interventions among preschool children? A systematic review. Clinical Obesity, 8(4), 285-299. https://doi.org/10.1111/cob.12253

Pratiwi, W. N., Rochintaniawati, D., \& Agustin, R. R. (2018). The effect of multiple intelligence-based learning towards students' concept mastery and interest in learning matter. Journal of Physics: Conference Series, 1013, 012075. https://doi.org/10.1088/1742-6596/1013/1/012075

Ratnasari, I. T., Wardani, S., \& Nuswowati, M. (2018). The impact of multiple intelligences approach through quantum teaching model toward the scientific attitude and science learning outcomes in the fourth grade students. Journal of Primary Education, 7(2), 146-154. https://journal.unnes.ac.id/sju/index.php/jpe/article/view/21979

Saban, A. (2015). Conceptions of learning in light of the MI theory. Procedia - Social and Behavioral Sciences, 186, 231-237. https://doi.org/10.1016/j.sbspro.2015.04.134

Samsudin, M. A., Haniza, N. H., Talib, C. A., \& Ibrahim, H. M. M. (2015). The relationship between multiple intelligences with preferred science teaching and science process skills. Journal of Education and Learning, 9(1), 53-59. http://eprints.utm.my/id/eprint/54030/

Şener, S., \& Çokçalışkan, A. (2018). An investigation between multiple intelligences and learning styles. Journal of Education and Training Studies, 6(2), 125-132. http://www.redfame.com/journal/index.php/jets/article/view/2643

Sengupta, A. (2017). Internet-based approach to multiple intelligences: Multiple provisions for multiple learners. Journal of Technology for ELT, 7(2).

Shearer, C. B. (2018). Multiple intelligences in teaching and education: Lessons learned from neuroscience. Journal of Intelligence, 6(3), 38. https://doi.org/10.3390/jintelligence6030038

Shearer, C. B., \& Karanian, J. M. (2017). The neuroscience of intelligence: Empirical support for the theory of multiple intelligences? Trends in Neuroscience and Education, 6, 211-223. https://doi.org/10.1016/j.tine.2017.02.002

Stanciu, D., Orban, I., \& Bocos, M. (2011). Applying the multiple intelligences theory into pedagogical practice. Lessons from the Romanian primary education system. Procedia - Social and Behavioral Sciences, 11, 92-96. https://doi.org/10.1016/j.sbspro.2011.01.040

Sternberg, R. J. (2014). Teaching about the nature of intelligence. Intelligence, 42, 176-179. https://doi.org/10.1016/j.intell.2013.08.010

Sutcu, N. D., Sutcu, K., \& Bulut, I. (2015). Examination of the relationship between classroom teachers' multiple intelligence areas and their students' academic achievements. The Anthropologist, 22(2), 309-317. https://doi.org/10.1080/09720073.2015.11891882

Uswatun, D. A., \& Rohaeti, E. (2015). Perangkat pembelajaran IPA berbasis inkuiri untuk meningkatkan critical thinking skills dan scientific attitude siswa. Jurnal Inovasi Pendidikan IPA, 1(2), 138. https://doi.org/10.21831/jipi.v1i2.7498

Utami, D. N., \& Aznam, N. (2020). Pengembangan LKPD IPA “Pesona Pantai Parangtris" berbasis learning cycle 7E beserta efeknya terhadap critical thinking. Jurnal Inovasi Pendidikan IPA, 6(1). https://doi.org/10.21831/jipi.v6i1.30404

Voogt, J., \& Knezek, G. (2008). International handbook of information technology in primary and secondary education. Springer Science \& Business Media.

Winarti, A., Yuanita, L., \& Nur, M. (2019). The effectiveness of multiple intelligences based teaching strategy in enhancing the multiple intelligences and science process skills of junior High School students. Journal of Technology and Science Education, 9(2), 122. https://doi.org/10.3926/jotse.404

Wolff, F., Nagy, N., Helm, F., \& Möller, J. (2018). Testing the internal/external frame of reference model of academic achievement and academic self-concept with open self-concept reports. Learning and Instruction, 55, 58-66. https://doi.org/10.1016/j.learninstruc.2017.09.006

Yalmanci, S. G., \& Gozum, A. I. C. (2013). The effects of multiple intelligence theory based teaching on students' achievement and retention of knowledge (example of the enzymes subject). 
Jurnal Inovasi Pendidikan IPA, 6 (1), 2020 - 113

Lukman Nulhakim, Liska Berlian

International Journal on New Trends in Education and Their Implications, 4(3), 27-36. http://www.ijonte.org/FileUpload/ks63207/File/complete.pdf\#page=33

Yerizon, Y., Putra, A. A., \& Subhan, M. (2018). Student responses toward student worksheets based on discovery learning for students with intrapersonal and interpersonal intelligence. IOP Conference Series: Materials Science and Engineering, 335, 012113. https://doi.org/10.1088/1757899X/335/1/012113 